\title{
The age and the flushing time of the Great Barrier Reef waters
}

\author{
FERNANDO P. ANDUTTA ${ }^{1,2, ~ *}$, PETER V. RIDD ${ }^{1}$, E. WOLANSKI ${ }^{3,4}$ \\ ${ }^{1}$ School of Engineering and Physical sciences, James Cook University, Townsville, Qld. 4811,
} Australia.

${ }^{2}$ School of Physical, Environmental and Mathematical Sciences, University of New South Wales at Australian Defence Force Academy UNSW-ADFA, ACT 2600, Australia.

3 School of Marine and Tropical Biology, James Cook University, Townsville, Qld., 4811, Australia.

${ }^{4}$ Australian Institute of Marine Science, Townsville, Australia.

*Corresponding author. Email: f.andutta@adfa.edu.au

\section{ABSTRACT}

A numerical model of the Great Barrier Reef (GBR) was verified using water current data from twenty sites, and applied to estimate the flushing time and age of waters. These timescales were calculated under different wind and oceanic inflow conditions. The age of oceanic waters intruding in the GBR was estimated to be between 3 and 5 months on leaving the GBR, depending on the location; the largest residence time prevailed in the southern GBR matrix where the age was the highest within the high density reef matrix, indicating veering of the mean currents around the GBR matrix. The flushing time depends on the size of the domain, and was estimated to be 67 days for the whole central GBR. For the flushing of coastal waters the wind had two effects. Firstly, it increased the flushing times by generating wind-driven currents, transporting some water back to the source; this process is comparable to that of an estuary, where water that leaves the estuary at ebb tide may return at flood tide, a process parameterized by the return coefficient. The return coefficient in the GBR due to wind reversals may be as large as $50 \%$ at the timescale of the wind. Secondly, in the southern and central regions of the GBR, the southeasterly tradewind deflected the southward flowing oceanic inflow seaward, away from the inner shelf and towards the outer shelf, making room for a wind-driven current of opposite direction on the inner shelf. Thus the intrusion of oceanic water in the GBR depends on the wind over the GBR. The veering of the mean currents around the GBR reef matrix and the wind over the 
1 shelf influencing the oceanic circulation demonstrate small scales (the GBR shelf) influencing the large 2 scale oceanic circulation.

Keywords: flushing time; age; Coral Sea inflow; North Caledonian Jet; residual circulation; mixing.

\section{Introduction} biological oceanographers because they are important parameters for determining estuarine ecosystem health, as well as its sensitivity to pollution threats (Lucas et al., 2009; McLusky and Elliott, 2004;

11 Wolanski, 2007; Wolanski, et al., 2012). Physical oceanographers have provided a number of definitions of water transport timescales. The flushing time is defined as the time necessary for a concentration to decrease to 1/e ( 0.37) of its initial concentration (Ketchum, 1950; Dyer, 1973; Deleersnijder et al., 2006). Flushing time is an integrative parameter used to describe the water body exchange, without identifying the mass concentration distribution in the domain (Monsen et al., 2002; Valle-Levinson, 2010). To incorporate this spatial distribution the residence time is used, which is the time taken for a water particle to initially exit a domain; thus the residence time depends on the release time and location (Delhez and Deleersnijder, 2006; Monsen et al., 2002). For the residence time, once water particles have crossed one of the domain's open boundaries for the first time, these particles are assumed to never return. In practice, however, some of these particles may return with reversing tidal currents in an estuary, or by other physical mechanisms in different aquatic systems (Monsen et al., 2002). To account for the excess time in which water particles re-enter a specific domain, exposure time is used. The exposure time is defined as the total time that a particle of water spends inside the estuary; this time accounts for the period in which water particles re-enter the estuary (Delhez, 2006). The age is the time necessary for a water particle to move from a defined inlet boundary to another specific location (e.g. the mouth of an estuary); thus particles released at different boundary inflow locations show different ages (Monsen et al., 2002). The return coefficient, a non-dimensional parameter, is used to quantify the propensity of particles to return into a pre-defined domain after crossing one of its open boundaries for the first time. This coefficient is defined as the ratio of the difference between the exposure time and the residence time, to the exposure time, and ranges between 0 and 1 . The return coefficient is close to unity for areas where water particles have a higher propensity to re-enter the domain, and is zero for areas 
1 where particles never re-enter the domain after crossing one of its open boundaries for the first time 2 (Arega et al., 2008; de Brauwere et al., 2011).

For the Great Barrier Reef of Australia (GBR; Figure 1), it is not possible to adequately estimate these time scales using physical tracers, because such data are unavailable. An alternative approach is to use numerical models by tracking hundreds to thousands of virtual tracers (Wolanski, 2007; Andutta et al., 2012).

It is a challenge to model the GBR properly due to the large scale of the system combined with the small scale of the individual reefs. Although typically only a few hundred meters in size, these reefs can be present in a dense array, inhibiting the large-scale circulation. The resulting feedbacks between scales are complicated. The large scale oceanic circulation influences the small scales circulation around individual reefs, while small scale circulation in and around a reef matrix influences the circulation at large scales by the sticky water effect (Wolanski et al., 2003; Andutta et al., 2012). Dight et al. (1990) used a $9.26 \mathrm{~km}$ mesh size to simulate currents and larval dispersion in the GBR. Brinkman et al. (2001) and King and Wolanski (1996) used a smaller mesh size of nearly $2 \mathrm{~km}$; they showed the importance of the Coral Sea inflow to flush the shelf, even in the absence of wind. Luick et al. (2007) used a model with a mesh size of $1.8 \mathrm{~km}$ to study transport time scales of the GBR. These finite-difference models all suffered from insufficient horizontal resolution of the reef matrix, as the grids were too coarse to resolve the complex bathymetry that requires a mesh size no larger than $300 \mathrm{~m}$ near reefs. These low horizontal resolution models ignored many of the individual reefs that are less than $2 \mathrm{~km}$ in size, along with their associated eddies, as well as reef passages between ribbon reefs. Thus they did not properly simulate the dispersive processes near reefs.

This study uses a high-resolution, non-structured numerical model (Lambrechts et al., 2008; Andutta et al., 2011, Andutta et al., 2012) to estimate transport timescales in the GBR, namely the flushing time and the age of waters. The mesh size was calculated as a function of distance from both the coastline and the bathymetry. Cells of about $300 \mathrm{~m}$ were used near reefs, islands and the coast, while cells of a few kilometers were used in deeper regions far from the coast and the reefs. This use of variable dimension cells allowed the high velocity shear zones close to reefs and wakes of islands, as well as the tidal jets between narrow passages to be represented appropriately (Lambrechts et al., 2008).

The Second-generation Louvain-la-Neuve Ice-ocean Model (SLIM), is a 2D vertical integrated model, and can be used to represent the hydrodynamics within the GBR. This model is suitable because the baroclinic circulation due to salinity stratification is confined to short periods, e.g. a few weeks in 
1 duration in the wet season (Wolanski and van Senden, 1983), and upwelling events at the shelf break

2 (Andrews and Furnas, 1986). This is the first numerical model applied to the GBR that has been previously calibrated to accurately model mixing processes. This calibration was achieved by comparing model results with salinity measurements during the dry season, i.e. measurements of hypersaline coastal waters in the GBR (Andutta et al., 2011). The suitability of using 3D models with low horizontal resolution, as opposed to 2D vertical integrated models with high horizontal resolution, was addressed by Luick et al. (2007) who showed that, in view of the prevailing shallow waters in the GBR, 3-D models may not be needed because little vertical stratification of salinity and temperature was found in most areas, except near river mouths during the short-lived wet season, and thus the local baroclinic circulation was negligible.

Different methods have previously been used to estimate time scales in the GBR, with results showing both relatively short timescales, $c a$. a few weeks (Hancock et al., 2006; Wang et al., 2007), and

13 large time scales, nearly one year (Luick et al., 2007). Hancock et al. (2006) and Wang et al. (2007)

14 found much shorter estimates of residence time (a few weeks) using measurements of salinity and 15 radionuclides.

The coefficients of horizontal viscosity and diffusivity are other limitations of many models. To simulate sub-grid scale processes, assumptions are required to choose the values of the horizontal eddy 18 diffusion and eddy viscosity coefficients, which usually depend on grid size. Okubo (1971) found an empirical relationship between the apparent diffusivity and the scale of diffusion. From his studies, a diagram was given to predict the rate of the horizontal spread from an instantaneous source. This study did not provide any parameterization to solve turbulent diffusion at the sub-grid scale in numerical models. Turbulent diffusion is likely to depend on the area of each grid cell, as well as on the velocity shear between the boundaries of the grid cell. Smagorinsky (1963) provided a parameterization of the horizontal diffusion of momentum, which can be used to calculate the horizontal viscosity coefficient at the sub-grid scale in numerical models such as SLIM. The proposed parameterization calculates the horizontal viscosity coefficient from the velocity shear between the boundaries of each grid cell, and is therefore dependent on the grid size. Despite this advance, many numerical models still use a constant 28 value for the horizontal viscosity coefficient, which needs to be adjusted and is often unknown a priori. 29 To adjust horizontal diffusion at the sub-grid scale, we have used the diffusion $K_{h}$ as a function of the 30 mesh size, and a formulation provided by Okubo (1971). Details are shown by Andutta et al. (2011 and 31 2012). 
The offshore open boundary conditions of the GBR are forced by tides and water inflow from the adjoining Coral Sea; however, this inflow is not always well known in terms of volume and entry position. The oceanic inflow inside the GBR is mainly caused by the North Vanuatu Jet (NVJ), the North Caledonian Jet (NCJ), and the South Caledonian jet (SCJ) (Ganachaud et al., 2007; Ganachaud et al., 2008). These jets originate from the South Equatorial Current (SEC) (Andrews and Clegg, 1989). The SEC and the three jets are free inertial turbulent jets (Burrage et al., 1991) with high spatial and time variability. As the NCJ approaches the continental shelf slope, it splits into three components. The southward component is known as the East Australian current (EAC), the northward component is the North Queensland current (NQC), and the remaining fraction enters the GBR across low reef density areas (Ganachaud, 2008; Andutta et al., 2011; Andutta, et al., 2012). Geostrophic calculations show that these currents approach the shelf-break between 15 and $20^{\circ} \mathrm{S}$ (Church, 1987). To adequately represent the circulation within the GBR, Brinkman et al. (2001) adjusted the NCJ inflow to between 14.7 and $16.75^{\circ} \mathrm{S}$. The NCJ inflow splits into two branches when meeting the shelf slope; a small part is able to cross the reef matrix, mostly in low density reef areas, thus causing a residual onshore circulation inside the GBR (Andutta et al., 2011).

In this paper, these timescale estimates were re-calculated to take into account the wind-driven return flows that can return particles to the source, a process that has so far been neglected in the GBR. 18 The return coefficient is as large as 50\% over the time scale of a wind event. In addition the wind wind-driven current of opposite direction on the inner shelf. The GBR can thus be viewed as a giant estuary where the 'river' is the oceanic inflow from the Coral Sea, the buoyancy effects are negligible, the tides are important to generate mixing, and the wind generates flow reversals resulting in a return coefficient that inhibits flushing of the GBR. The age of the inflow is as large as 7 months on leaving the GBR. It shows steering of the mean circulation around the high density southern GBR matrix.

\section{Methods}

\section{The model}

The SLIM model was used, which has previously been used for studies involving the GBR (Legrand et al., 2006; Lambrechts et al., 2008; Andutta et al., 2011 and 2012). SLIM is a free-surface, hydrostatic, depth-averaged, primitive equation ocean model that uses unstructured mesh and terrain 
1 following coordinates. While all other models of the GBR are finite-difference models, SLIM is a finite

2 element model with variable size cells and is well suited to the complex topography of the GBR matrix

3 (Figure 1B). The model uses grid cells in the range of $150 \mathrm{~m}$ near reefs to nearly $20 \mathrm{~km}$ in open water 4 far from reefs (Figure 1B).

5 This model accurately reproduces (Andutta et al., 2011; Andutta et al., 2012) the following 6 observations: the mean southward current at the mooring sites at Myrmidon Reef, Old Reef, and Cape 7 Upstart (Figure 1), which reverses during southeasterly winds (Burrage et al., 1997; Andrews, 1983); the 8 tidal currents oriented across the shelf in the central region of the GBR and longshore in the southern 9 region (Church et al., 1985); and the splitting of the residual southward flow into two branches as it 10 approaches the high reef density area (Figure 1C), with one branch channelling between the reef matrix 11 and the coast, and the other branch located along the reef matrix offshore from the GBR (Brinkman et 12 al., 2001).

13 The estimates of flushing time and age were made by a Lagrangian scheme that used up to 14300,000 virtual drifters. The model avoids negative diffusion effects near sloping boundaries, a problem 15 that affects many 2-D models (Spagnol et al., 2002). To estimate the age of the NCJ inflow, the virtual 16 drifters were released at the open boundary $(Q)$, which is where the NCJ inflow enters the GBR (Figure 17 1B). Virtual particles were released at the same time on the $1^{\text {st }}$ of August 2006 (in neap tides). However, 18 if particles were released in spring tides the age results would differ only slightly because of the 19 extensive length between the inflow open boundary and the southern exit flow (near Capricorn 20 passage), which is nearly 800 kilometers.

21 To estimate the flushing time, the drifters were released in the study areas shown in Figure 1A 22 and labelled B (bays), N (North), C (central), and S (South); these domains include 5 bays, 3 inshore 23 regions, and 3 mid-shelf regions with alongshore and cross shelf dimensions of $100 \mathrm{~km}$ by $30 \mathrm{~km}$, 24 respectively. Flushing time was calculated as the mean result from simulations starting and neap and 25 spring tides, i.e. simulations starting at neap ( $1^{\text {st }}$ of August 2006) and spring tides ( $8^{\text {th }}$ of August 2006).

\section{Preferred position for Figure 1}


The wind field data were provided by the Australian Institute of Marine Science (AIMS) and measured at Rib Reef (18 $28^{\circ} 50^{\prime}$ S, $146^{\circ} 52^{\prime} 12^{\prime}$ E), and the simulations under real wind conditions started at $1^{\text {st }}$ of August 2006 (Andutta et al., 2011). The wind stress was assumed to be spatially uniform.

Sea level data from TOPEX were used to force tides at the open boundaries.

The inflow, $Q$, from the Coral Sea, by the NCJ, was modelled following Andutta et al (2011); $Q$ was set to either $0 \mathrm{~Sv}$ or $4 \mathrm{~Sv}\left(1 \mathrm{~Sv}=10^{6} \mathrm{~m}^{3} \mathrm{~s}^{-1}\right)$ and applied to the open boundary, between $\sim 16.3^{\circ} \mathrm{S}$ and $\sim 17.4^{\circ} \mathrm{S}$ (Figure 1B). The southern open boundary was forced to drain the flow volume of $0.7 \times Q$, while in the northern GBR the open boundary was forced to drain the remaining $0.3 \times Q$.

For testing combination by different forcings, five different scenarios have been considered and these are listed in Table 1.

\section{Preferred position for Table 1}

\section{The physical parameters}

High values of the Manning coefficient, $\mathrm{n}$, were used over the reef zones $\left(0.15-0.25 \mathrm{~m}^{-1 / 3} \mathrm{~s}\right)$ and lower values $\left(0.025 \mathrm{~m}^{-1 / 3} \mathrm{~s}\right)$ were used elsewhere (Andutta et al., 2011; Andutta et al., 2012).

The eddy viscosity parameterization was used to solve diffusion of momentum to the sub-grid scale (Smagorinsky, 1963). The coefficient for the horizontal diffusion of mass, $K_{h}$, is assumed to be a function of the mesh size, and thus constant in time. A modification of the empirical formula from Okubo (1971) was used to solve the macro-turbulence generated by a complex bathymetry, i.e.

$$
K_{h}=f\left[2.05 \times 10^{-4} \times r^{1.15}\right]
$$

\section{Preferred position for Table 2}

where $r$ is the length scale, which in this study is assumed to be the grid resolution, and $f$ is a factor that has been introduced to the formula of Okubo (1971). An $f$ value of 20 was required in order for the model results to fit field observations of the GBR coastal hypersaline zone during the dry season (Andutta et al., 2011).

\section{Transport timescales simulations}


We calculated the flushing time as the time taken for $63 \%$ of the particles to exit the domain for the first time (Deleersnijder et al., 2001). This was implemented by applying an initial concentration of virtual drifters in the region of interest, with zero drifters in all other areas. We used 300,000 virtual particles inside the $100 \mathrm{~km} \mathrm{X} 30 \mathrm{~km}$ areas, and for the bays we used 1,000 particles $\mathrm{km}^{-2}$. The flushing time of a particular box is dependent upon the box area and thus, aside from the boxes covering the bays, the boxes over the shelf were chosen to be of similar area and mean depth so that flushing times could be compared between different locations along the GBR. We have, however, provided and formulation to estimate the age is described in detail by Arega et al., (2008) and de Brauwere et al., (2010). Virtual drifters were released at the open boundary (shown in Figure 1), and their positions were recorded for every time-step, and further used to generate age contours, i.e. the front line of the cloud of particles. To estimate the return coefficient $(r)$ we have considered scenarios $S_{3}, S_{4}$ and $S_{5}$, using the following equations,

The mean concentration value was computed inside each area according to the number of particles remaining in the sub-domains, and the timescales were calculated for scenarios $S_{1}$ to $S_{5}$ (Table $1)$.

\section{The return coefficient was estimated for the coastal areas and bays in the GBR, and the}

$$
r\left(S_{3}\right)=\frac{\phi\left(S_{3}\right)-\varphi\left(S_{3}\right)}{\phi\left(S_{3}\right)} ; r\left(S_{4}\right)=\frac{\phi\left(S_{4}\right)-\varphi\left(S_{4}\right)}{\phi\left(S_{4}\right)} ; r\left(S_{5}\right)=\frac{\phi\left(S_{5}\right)-\varphi\left(S_{5}\right)}{\phi\left(S_{5}\right)}
$$

where $\varphi$ is the time necessary for $63 \%$ of particles to exit the domain for the first time, while $\phi$ is the total time that $63 \%$ of particles spend inside the domain. Therefore $\varphi>\phi$ when over $63 \%$ of the particles re-entered the domain. This is a similar consideration to that of exposure time and residence time; however, we only control the total number of particles inside the domain and do not consider the spatial distribution of particles inside each sub-domain. negligible fraction of particles returned to their source.

The return coefficient for scenarios $S_{1}$ and $S_{2}$ was negligible because under calm weather a

For the age estimates, we assumed a Coral Sea inflow $Q=4 \mathrm{~Sv}$ for scenarios $\mathrm{S}_{2}$ to $\mathrm{S}_{5}$ (Table 1). For scenario $S_{1}$ the Coral Sea inflow was not applied and therefore the age could not be computed. For $S_{2}$ to $S_{5}$ the age was computed as the elapsed time of particles deployed initially at the boundary where 
1 the NCJ enters the GBR (Figure 1); the contours of the age were computed similar to Shen and Hass

2 (2004). Age, residence time, and exposure time do not provide the location of water particles at different times. Because of this we provided one extra simulation in which the positions of water particles were recorded in time. We released 10,000 virtual particles in coastal waters near Townsville $\left(19^{\circ} \mathrm{S}, 147^{\circ} \mathrm{E}\right)$, and thus quantified the alongshore travel distance in time, under different wind conditions (see scenarios in table 1). This provides powerful results that help the interpretation of the age, residence time, and exposure time of waters in coastal areas. The average position of the particle cloud, at different times, was calculated using the average latitude and longitude coordinates from these particles, with the error bar representing the deviation.

\section{3. Results}

The residual currents were accurately simulated by the numerical model (Table 2). The formation of the dry season hypersaline coastal layer was well simulated, as were the tidal currents at all the mooring sites (Andutta et al., 2011).

\section{Flushing time and return coefficient}

which are shown in Figure 1 (Table 3). In addition, this table shows the percentage of a conservative concentration in these areas after 12 and 24 days.

The flushing time for scenario $S_{2}$ is $\sim 0.5-1.5$ weeks for the inshore and mid-shelf areas, and 0.5-3 weeks for bays 1 to 5 . For scenarios $S_{3}$ and $S_{4}$, the flushing time $\phi$, increased in inshore and midshelf areas, and decreased in the bays (Table 3). For scenario $S_{3}, \phi$ was $\sim 0.5-3$ weeks for inshore and mid-shelf areas and 0.5-2 weeks for the bays. For scenario $\mathrm{S}_{4}, \phi$ was $\sim 0.5-4.0$ weeks for inshore and mid-shelf areas and 0.5-2 weeks for the bays. The flushing times in the bays were slightly lower for scenario $\mathrm{S}_{4}$ than for scenario $\mathrm{S}_{3}$.

The return coefficient was calculated for these inshore and mid-shelf areas, and indicates the propensity of particles to return to their source (Table 3 ). For scenarios $S_{1}$ and $S_{2}$ there was zero return of water particles. In contrast, for scenarios $S_{3}$ and $S_{4}$ the largest return coefficients were calculated for $\left(\mathrm{C}_{\mathrm{i}}\right)$, although in the northern area $\left(\mathrm{N}_{\mathrm{i}}\right)$ this coefficient was also relatively large, $\mathrm{r} \sim 0.40-0.55$. For scenario $S_{5}$, the real wind increased the flushing time compared to scenario $S_{2}$ (calm weather). In 
1 addition, the SE wind caused the return of waters during short periods, e.g. simulation days 50 and 80 .

2 For scenario $\mathrm{S}_{5}$, the timescale for the return of waters was different from the time taken for the number of particles to decrease to 0.37 , and thus $r$ was not calculated.

The flushing time for $Q=0$ and zero wind for scenario $\mathrm{S}_{1}$ was 5-8.5 weeks in the six coastal zones, and 1-6 weeks in the bays (Table 3). Scenario $S_{1}$ resulted in the largest flushing time because tidal mixing was the only remaining mixing mechanism for that scenario. The effect of the wind was that flushing times in the bays decreased (Table 3) because alongshore wind-driven residual currents inhibited water particles from returning to their source bay. For the whole central GBR, the flushing times varied from 1 to 9 months (Table 3). Results were $\sim 6.5$ weeks for scenario $\mathrm{S}_{2}$. For scenarios $\mathrm{S}_{3}$ and $\mathrm{S}_{4}$, the flushing time $\phi$ was $\sim 12-15$ weeks, respectively. The largest flushing time of $\sim 9$ months was obtained for $\left(\mathrm{S}_{1}\right)$, i.e. calm weather with no inflow $Q$. For the real wind in scenario $\mathrm{S}_{5}$, the flushing time of the central GBR was $\sim 9.5$ weeks.

Under calm weather, changing the inflow from $0 \mathrm{~Sv}$ to $4 \mathrm{~Sv}$ resulted in a 3.5 to 10 fold reduction in flushing times (for no wind conditions) for the inshore and mid-shelf zones. $\mathrm{S}_{\mathrm{i}}$ showed the most dramatic reduction (from 60 to 5.5 days), which was due to the Coral Sea inflow (Table 3). For the bays, the influence of the Coral Sea inflow was also reduced because the alongshore transport of particles inhibited the reversal tidal currents from transporting these particles back into the bays, i.e. negligible return coefficient.

\section{Preferred position for Table 3}

Flushing time curves from coastal area $\mathrm{C}_{\mathrm{i}}$ and bay $\mathrm{B}_{5}$ are shown for scenarios $\mathrm{S}_{2}$ and $\mathrm{S}_{4}$ (Figure 2A). These curves illustrate some of the results from Table 3, and exemplify how wind conditions may affect the flushing times of water particles in coastal waters and bays in the central GBR. For all scenarios, the flushing times of water particles vary between different areas of the GBR, for both inshore and mid-shelf zones (not shown in Figure 2), summarized in Table 3. This shows the potential deficiency of the 1D models of the GBR, these 1D models lack the influence of the alongshore residual circulation, and therefore miscalculate the transport timescale (Hancock et al., 2006; Wang et al., 2007).

Results from scenario $\mathrm{S}_{4}$ (Figure $2 \mathrm{~A}$ ), showed that southeasterly winds transport water back to its source in coastal areas, while for the bays, the flushing time decreases under this wind condition because 
1 water particles are transported out of the bays. This process, i.e. the return of waters to its source, was also observed for scenarios $\mathrm{S}_{3}$ and $\mathrm{S}_{5}$ (shown only for the whole GBR, Figure 2B).

The flushing time curve is also shown for the entire central GBR for a 90 day period (Figure 2B), calculated from scenarios $S_{1}$ to $S_{5}$, and from the measured wind data shown in Figure $2 C$. During calm weather and zero Coral Sea inflow, the flushing of water from the GBR considerably decreases, i.e. scenario $S_{1}$. However, the flushing time is most reduced with calm weather and the Coral Sea inflow applied, i.e. scenario $S_{2}$. For scenarios $S_{3}$ to $S_{5}$, where $S E$ wind conditions alternate with calm weather events, flushing time curves were observed to lie between the curves from scenarios $S_{1}$ and $S_{2}$. These results indicate that fluctuating wind conditions may double the flushing time for the central GBR. This increase in flushing time is caused by the return of waters by the northward wind-driven current (e.g.

11 from scenarios $\mathrm{S}_{3}, \mathrm{~S}_{4}, \mathrm{~S}_{5}$ ).

Preferred position for Figure 2

\section{The alongshore transport of water particles}

Figure 3 shows the alongshore transport of particles deployed at coastal waters near Townsville (Figure 1C). Under zero wind in scenario $\mathrm{S}_{2}$, the water particles moved southward (Figure 3A), and for the three month period these particles travelled a distance of $\sim 350 \mathrm{~km}$. In contrast, when a fluctuating 18 southeasterly wind was applied (scenarios $S_{3}$ and $S_{4}$ ) for 10 day periods, followed by calm weather conditions, the water particles moved back and forth near the coast, and thus the southward net transport was reduced (Figure 3). After nearly three months, the particles released at coastal waters near 21 Townsville had travelled southwards distances of $\sim 170 \mathrm{~km}$ and $\sim 40 \mathrm{~km}$ for scenarios $\mathrm{S}_{3}$ and $\mathrm{S}_{4}$, respectively. For the real wind conditions in scenario $\mathrm{S}_{5}$, the particles were transported southwards, with short transport in the opposite direction under SE winds, and thus this southward transport was slower than for calm weather conditions (Figure 3A).

\section{Preferred position for Figure 3}

Age of the Coral Sea water inflow

Results of the Coral Sea inflow are shown in figures 4A to 4C, and the location of the inflow, $Q$, is shown in figure 1 . Figures $4 \mathrm{~A}$ and $4 \mathrm{C}$ do not show the area from the boundary inflow $\mathrm{Q}$, as this would give poor details of Age contours. For zero wind, shown in Figure 4A, under scenario $\mathrm{S}_{2}$ the southward

30 flow is fast near the shelf break, with water particles exiting the domain in the southern GBR in less than 312 months. The water that entered the GBR lagoon, however, took over 5 months to travel along the 
central and southern GBR in coastal areas. Bottom friction steers away most of the residual flow in high reef density areas, and thus water renewal within high reef density zones is reduced (Andutta et al., 2012). For conditions under calm weather (Figure 3A) and real wind (Figure 3D), the age of waters show the NCJ inflow splitting into two branches around the high reef density matrix, indicating high retention time of water in the reef matrix. This effect of high reef density areas steering the flow around and decreasing water renewal within these areas is known as the sticky water effect (Andutta et al., 2012). coastal boundary layer. Water particles were transported back and forth near the coast, while spreading cross-shelf. A small fraction of particles crossed the reef matrix towards the shelf-break and were then quickly transported southwards outside the lagoon by the EAC, with speed of $\sim 0.2$ to $0.3 \mathrm{~m} \mathrm{~s}^{-1}$. For scenario $\mathrm{S}_{4}$ (Figure 3C), intruding oceanic waters did not flow southwards between the reef matrix and the coast in the southern GBR, i.e. between 20 and $23^{\circ} \mathrm{S}$. These results show a trapped water mass forming a coastal boundary layer (Figures 3B and 3C) in which the current is northward with the wind.

18 For the real wind scenario $\mathrm{S}_{5}$, the NCJ inflow between the reef and the coast was reduced and a fraction of this inflow was deflected outside the lagoon.

A conceptual model summarizing the results of the age of waters is shown in Figures 4A and 4B. For calm weather conditions (Figure 5A), a large fraction of the NCJ inflow moves alonghsore southwards, largely splitting in two bands. One band remains offshore from the GBR, while the other band flows between the coast and the GBR; this circulation reduces water trapping in coastal areas and offshore from the GBR. This is evidenced by the MODIS satellite image of chlorophyll-a concentration (Figure 5C). In contrast, under southeasterly wind, there is reduced flushing of inshore water; the wind not only deflects a larger fraction of the NCJ inflow to the outer GBR, it also generates a wind driven current of opposite direction in coastal areas (Figure 5B). This is evidenced by the MODIS satellite of true ocean color (Figure 5D), where a turbid nearshore zone was observed south of $19.5^{\circ} \mathrm{S}$ with its width 
1 increasing southwards. This turbulent zone indicated that new, clear water, oceanic inflow into the GBR

2 was deflected seaward, while the turbid coastal waters intruding from the south were unable to 3 propagate past $19.5^{\circ} \mathrm{S}$. A similar process of the local wind over the shelf preventing oceanic inflow 4 onto a continental shelf has been observed in other systems (Haley and Lermusiaux, 2010; Ramp et al., 5 2011).

\section{Preferred position for Figure 5}

\section{4. Discussion and conclusions}

The calculation of the age of oceanic water as it intrudes in the GBR shows the inflow splitting into two branches around the high reef density matrix, indicating high retention time of water in the reef matrix. This is another demonstration of the sticky water effect (Andutta et al., 2012).

This study shows that the NCJ inflow and the fluctuating southeasterly wind increase the 15 flushing times in coastal waters. Additionally, it shows that the reversing wind driven currents transport some water back to the source. This process in the GBR is similar to that in an estuary, where water leaving the estuary at ebb tides may return later at flood tide, a process parameterized by the return 18 coefficient (Lermusiaux, 2001; Haley et al., 2009). In estuaries, the reversing tidal currents increase the propensity of water particles to return to the estuary for a few hours or even days (Arega et al., 2008; de Brauwere et al., 2010). In contrast, for the GBR the time required to transport water back to its source is a few weeks. The resulting return coefficient for the GBR may be as large as $50 \%$.

For the whole central GBR the flushing time was calculated to be 67 days for the real wind condition. The largest flushing time (i.e. $~ 9$ months) was calculated for calm weather and negligible NCJ inflow, which is a flushing time controlled by diffusion, i.e. tidal mixing. While the shortest flushing time (i.e. 1.5 months) was calculated under calm weather and with the NCJ inflow from the Coral Sea applied. For the bays, the flushing time was calculated to be between 0.5 to 6 weeks.

The principal mechanism for the flushing of the GBR is the oceanic inflow of the NCJ, which enters the central GBR on the outer shelf, and creates a mean current that replaces the GBR water with oceanic water. Additional to this process, are tidal mixing and wind-driven currents. 
Flushing times varied between different areas of the central GBR depending on the size and location of these areas. This identifies a potential flaw in the 1D models of Hancock et al. (2006) and Wang et al. (2007), which neglect the alongshore residual circulation.

A new finding is the importance of the unsteadiness of the wind. The reversing currents generate a high value for the return coefficient, as high as $50 \%$ over a time scale of several weeks.

Another new finding is that under southeasterly wind conditions, an inflow occurs in the southern GBR and prevails in coastal waters, flowing in the opposite direction to the mean current driven by the NCJ. As a result, the southeasterly wind was observed to deflect the southward flowing NCJ inflow seaward, away from the inner shelf and towards the outer shelf, making room for a winddriven current of opposite direction on the inner shelf. Thus the intrusion of oceanic waters on the GBR continental shelf decreases with increasing wind over the shelf; this is another demonstration, together with the sticky water effect (Andutta, 2012) of the feedback from the small scales to the large scales. A similar process was observed at the New Jersey shelf and on the continental shelf north of Monterey Bay

14 (Haley and Lermusiaux, 2010; Ramp et al., 2011).

\section{Acknowledgements}

The authors gratefully acknowledge the IPRS Fellowship to FPA.

\section{References}

Andrews, J.C., Clegg, S., 1989. Coral Sea circulation and transport from modal information models. Deep-Sea Research 36, 957-974.

Andrews, J.C., Furnas, M.J., 1986. Subsurface intrusions of Coral Sea Water into the central Great Barrier Reef-I. Structures and shelf-scale dynamics. Continental Shelf Research 6, 491-514.

Andrews, J.C., 1983. Water masses, nutrient levels and seasonal drift on the outer Central Queensland Shelf (Great Barrier Reef). Australian Journal of Marine and Freshwater Research 33, 717-722.

Andutta, F.P., Ridd, P.V., Wolanski, E., 2011. Dynamics of hypersaline coastal waters in the Great Barrier Reef. Estuarine Coastal and Shelf Sciences 94, 299-305.

Andutta, F.P., Kingsford, M., Wolanski, E., 2012. 'Sticky water' enables the retention of larvae in a reef mosaic. Estuarine Coastal and Shelf Science 101, 54-63. Arega, F., Armstrong, S., Badr, A.W., 
2008. Modeling of residence time in the East Scott Creek Estuary, South Carolina, USA, Journal of Hydro-environment Research 2, 99-108.

Brinkman, R., Wolanski, E., Deleersnijder, E, McAllister, F., Skirving, W., 2001. Oceanic inflow from the Coral Sea into the Great Barrier Reef. Estuarine, Coastal and Shelf Science 54, 655-668.

Burrage, D., Steinberg, C., Bode, L., Black, K., 1997. Long-term current observations in the Great Barrier Reef. In State of the GBR World Heritage Area Workshop, Proceedings of a Technical Workshop, Townsville, Australia, D. Wachenfeld et al. (Eds.), pp. 21-45 (Great Barrier Reef Marine Park Authority, 561 pp.

Burrage, D.M., Church, J.A., Steinberg, C.R., 1991. Linear systems analysis of momentum on the continental shelf slope of the Central Great Barrier Reef. Journal of Geophysical Research 96, 22169-22190.

Church, J.A., 1987. East Australian Current adjacent to the Great Barrier Reef. Australian Journal of Marine and Freshwater Research 38, 671-683.

Church, J.A., Andrews, J.A., Boland, F.M., 1985. Tidal currents in the central Great Barrier Reef. Continental Shelf Research 4, 515-531.

Deleersnijder, R., Beckers, J. M., Delhez, E. J. M., 2006. On the behavior of the residence time at the bottom of the mixed layer. Environmental Fluid Mechanics 6, 541-547.

Deleersnijder, E., Campin, J.M., Delhez, E.J.M., 2001. The concept of age in marine modeling. I. Theory and preliminary model results. Journal of Marine Systems 28, 229-267.

Delhez, E. J. M., 2006. Transient residence and exposure times. Ocean Science 2, 1-9.

Delhez, E. J. M., Deleersnijder, E., 2006. The boundary layer of the residence time field, Ocean Dynamics 56, 139-150.

de Brauwere A., de Brye, B., Blaise, S., Deleersnijder, E., 2010. Residence time, exposure time and connectivity in the Scheldt Estuary, Journal of Marine Systems 84, 85-95.

Dight, I.J., James, M.K., Bode. L., 1990. Modelling the larval dispersal of Acanthaster planci. II. Patterns of reef connectivity. Coral Reefs 9, 125-134.

Dyer, K.R., 1973. Estuaries: A physical Introduction. 2nd Edition. John Wiley, 195 pp.

Ganachaud, A., Gourdeau, L., 2008. Bifurcation of the subtropical south equatorial current against New Caledonia in December 2004 from a hydrographic inverse box model. Journal of Physical Oceanography 38, 2072-2084. 
Ganachaud, A., Kessler, W., Wijffels, S., Ridgway, K., Cai, W., Holbrook, N., Bowen, M., Sutton, P., Qiu, B., Timmermann, A., Roemmich, D., Sprintall, J., Cravatte, S., Gourdeau, L., Aung, T., 2007. Southwest Pacific Ocean Circulation and Climate Experiment. Part I. Scientific Background. NOAA OAR Special Report / International CLIVAR Project Office. C. P. S. N. 111.

Haley Jr., P.J., Lermusiaux, P.F.J., 2010. Multiscale two-way embedding schemes for free-surface primitive equations in the "Multidisciplinary simulation, estimation and assimilation system". Ocean Dynamics 60, 1497-1537.

Haley Jr., P.J., Lermusiaux, P.F.J., Robinson, A.R., Leslie, W.G., Logoutov, O., Cossarini, G. Liang, X.S., Moreno, P., Ramp, S.R., Doyle, J.D., Bellingham, J., Chavez, F., Johnston, S., 2009. Forecasting and reanalysis in the Monterey Bay/California Current region for the Autonomous Ocean Sampling Network-II experiment. Deep-Sea Research II 56, 127-148.

Hancock, G.J, Webster, I.T., Stieglitz, T.C., 2006. Horizontal mixing of Great Barrier Reef waters: Offshore diffusivity determined from radium isotope distribution. Journal of Geophysical Research 111(C12019), 14pp.

Ketchum, B.H., 1950. Hydrographic factors involved in the dispersion of pollutants introduced into tidal waters. Journal of the Boston Society of Civil Engineers 37, 296-314.

King, B.A., Wolanski, E., 1996. Tidal current variability in the Central Great Barrier Reef. Journal of Marine Systems 9, 187-202.

Lambrechts, J., Harnet, E., Deleersnijder, E., Bernard, P.E., Legat, V., Remacle, J.F., Wolanki, E., 2008. A multi-scale model of the hydrodynamics of the whole Great Barrier Reef. Estuarine, Coastal and Shelf Science 79, 143-151.

Legrand, S., Deleersnijder, E., Hanert, E., Legat, V., Wolanski, E., 2006. High-resolution unstructured meshes for hydrodynamics models of the Great Barrier Reef, Australia. Estuarine, Coastal and Shelf Science 68, 36-46.

Lermusiaux, P.F.J., 2001. Evolving the subspace of the three-dimensional multiscale ocean variability: Massachusetts Bay. Journal of Marine Systems 29, 385-422.

Lucas, L.V., Thompson, J.K., Brown, L.R., 2009. Why are diverse relationships observed between phytoplankton biomass and transport time? Limnology and Oceanography 54, 381-390.

Luick, J.L., Mason, L., Hardy, T., Furnas, M.J., 2007. Circulation in the Great Barrier Reef Lagoon using numerical tracers and in situ data. Continental Shelf Research 27, 757-778. 
Monsen, N.E., Cloern, J.E., Lucas L.V., Monismith, S.G., 2002. A Comment on the use of flushing time, residence time, and age as transport time scales. Limnology and Oceanography 47, 15451553.

McLusky, D.S., Elliott, M., 2004. The Estuarine Ecosystem: Ecology, Threats and Management. OUP,

$$
\text { Oxford, } 214 \mathrm{pp} \text {. }
$$

Okubo, A., 1971. Oceanic diffusion diagrams. Deep-Sea Research 18, 789-802.

Shen, J., Haas, L., 2004. Calculating age and residence time in the tidal York River using threedimensional model experiments. Estuarine, Coastal and Shelf Science 61, 449-461.

Smagorinsky, I., 1963. General Circulation Experiment with Primitive Equations. Monthly Weather Review 91, 91-164.

Spagnol, S., Wolanski, E., Deleersnijder, E., Brinkman, E., McAllister, F., Cushman-Roisin, B., Hanert, E., 2002. An error frequently made in the evaluation of advective transport in two-dimensional Lagrangian models of advection-diffusion in coral reef waters. Marine Ecology Progress Series 235, 299-302.

Ramp, S.R., Lermusiaux, P.F.J., Shulman I., Chao, Y., Wolf, R.E., Bahr, F.L., 2011. Oceanographic and atmospheric conditions on the continental shelf north of the Monterey Bay during August 2006. Dynamics of Atmospheres and Oceans 52, 192-223.

Steinberg, C., 2007. Impacts of climate change on the physical oceanography of the Great Barrier Reef. In: Johnson JE, Marshall PA (eds). Climate change and the Great Barrier Reef. Great Barrier Reef Marine Park Authority and Australian Greenhouse Office, Townsville, 51-74.

Valle-Levinson, A., 2010. Contemporary Issues in Estuarine Physics. Cambridge University Press, United Kingdom, 315pp.

Wang, Y., Ridd, P.V., Heron, M.L., Stieglitz, T.C., Orpin, A.R., 2007. Residence time of solutes and pollutants in the central Great Barrier Reef lagoon, Australia. Marine and Freshwater Research 58, 778-791.

Wolanski, E., 2007. Estuarine Ecohydrology. Elsevier, Amsterdam, 157 pp.

Wolanski, E., 1994. Physical oceanographic processes of the Great Barrier Reef. CRC Press, Boca Raton, Florida, 194 pp.

Wolanski, E., van Senden, D., 1983. Mixing of Burdekin River flood waters in the Great Barrier Reef. Australian Journal Marine Freshwater Research 34, 49-63. 
1 Wolanski, E., Brinkman, R., Spagnol, S., McAllister, F., Steinberg, C., Skirving, W., Deleersnijder, E., 2 2003. Merging scales in models of water circulation: Perspectives from the Great Barrier Reef. In: Advances in Coastal Modeling, V.C. Lakhan (ed.), Elsevier, Amsterdam, 411-429.

4 Wolanski, E., Andutta, F.P., Delhez, E., 2012. Estuarine hydrology. In: Encyclopedia of Lakes and 5 Reservoirs. Lars Bengtsson, Reginald Herschy, Rhodes Fairbridge (eds.), Springer, In press. 
Text for figures.

Figure 1 - (A) Map of Australia indicating the GBR location, (B) the numerical grid of the whole Great Barrier Reef with the resolution from about $150 \mathrm{~m}$ to $22 \mathrm{~km}$, and location of the Coral Sea inflow Q (between $a$ and $b$ ) used in the simulation. (C) The central section of the Great Barrier Reef lagoon, located north-eastern Australia. The mean flushing time was estimated for the bays $\mathrm{B}_{1}-\mathrm{B}_{5}$, and the $\left(\mathrm{S}_{\mathrm{i}}\right)$ South inshore, $\left(\mathrm{S}_{\mathrm{m}}\right)$ South middle zone, $\left(\mathrm{C}_{\mathrm{i}}\right)$ Central inshore, $\left(\mathrm{C}_{\mathrm{m}}\right)$ Central middle zone, $\left(\mathrm{N}_{\mathrm{i}}\right)$ North inshore and $\left(\mathrm{N}_{\mathrm{m}}\right)$ North middle zone. The arrows indicate the residual currents.

Figure 2 - The flushing time (A) for $C_{i}$ and $B_{5}$ under scenarios $S_{2}$ and $S_{4}$. (B) is the flushing time for the whole Central GBR, i.e. the 6 zones +5 bays, which is shown for the first 3 months of simulation for all scenarios. (C) is the daily averaged real wind measured at Rib Reef weather station $\left(18^{\circ} 28^{\prime} 50^{\prime}\right.$ ' $\mathrm{S}$, $146^{\circ} 52^{\prime} 12^{\prime}$ ' E) starting on $1^{\text {st }}$ of August 2006. All results from the different scenarios are summarized in Table 2.

Figure 3 - Alongshore travel distance of particles deployed initially at $\left(19^{\circ} \mathrm{S}, 147^{\circ} \mathrm{E}\right)$, near Townsville, in inshore waters in the zone $\mathrm{N}_{\mathrm{i}}$ (see figure 1). The scenarios were $\mathrm{S}_{2}$ to $\mathrm{S}_{5}$.

Figure 4 - Age of the NCJ inflow $(Q)$ in days is shown for scenarios $\mathrm{S}_{2}(\mathrm{~A}), \mathrm{S}_{3}(\mathrm{~B}), \mathrm{S}_{4}(\mathrm{C})$, and $\mathrm{S}_{5}$ (D). The age contours were calculated by releasing virtual drifters at the inflow open boundary between positions $\mathrm{a}$ and $\mathrm{b}$ shown in Figure 1.

Figure 5 - (A) Conceptual model describing long-term trapped water forming a coastal boundary layer increasing in width southwards. The coastal water trapping is caused by fluctuating southeasterly trade winds combined with the residual circulation from the Coral Sea inflow. (B) Model description of the age from the Coral Sea inflow under an idealized condition of long term calm weather. Age shows faster water renewal in the outer GRB than for areas over reefs, and between the reef matrix and the coast. In high reef density areas waters are poorly renewed. $U_{t}$ denotes the direction of tidal currents between high reef density areas and the coast, and $U_{R}$ the residual velocity. (C) MODIS chlorophyll-a image of the central and southern GBR showing oceanic (blue) water intruding in the central GBR and flowing southward inshore of the high reef density area. Red is high Chlorophyll-a or turbid water; blue is low Chlorophyll -a water; and black is land and cloud (Steinberg, 2007). Date was not provided in this reference. (D) MODIS satellite view of true ocean color of the central GBR on August 9, 2011. The satellite view indicated a coastal boundary layer with its width increasing southwards, which is similar to the conceptual model (B). 
Figure 1.

2 3

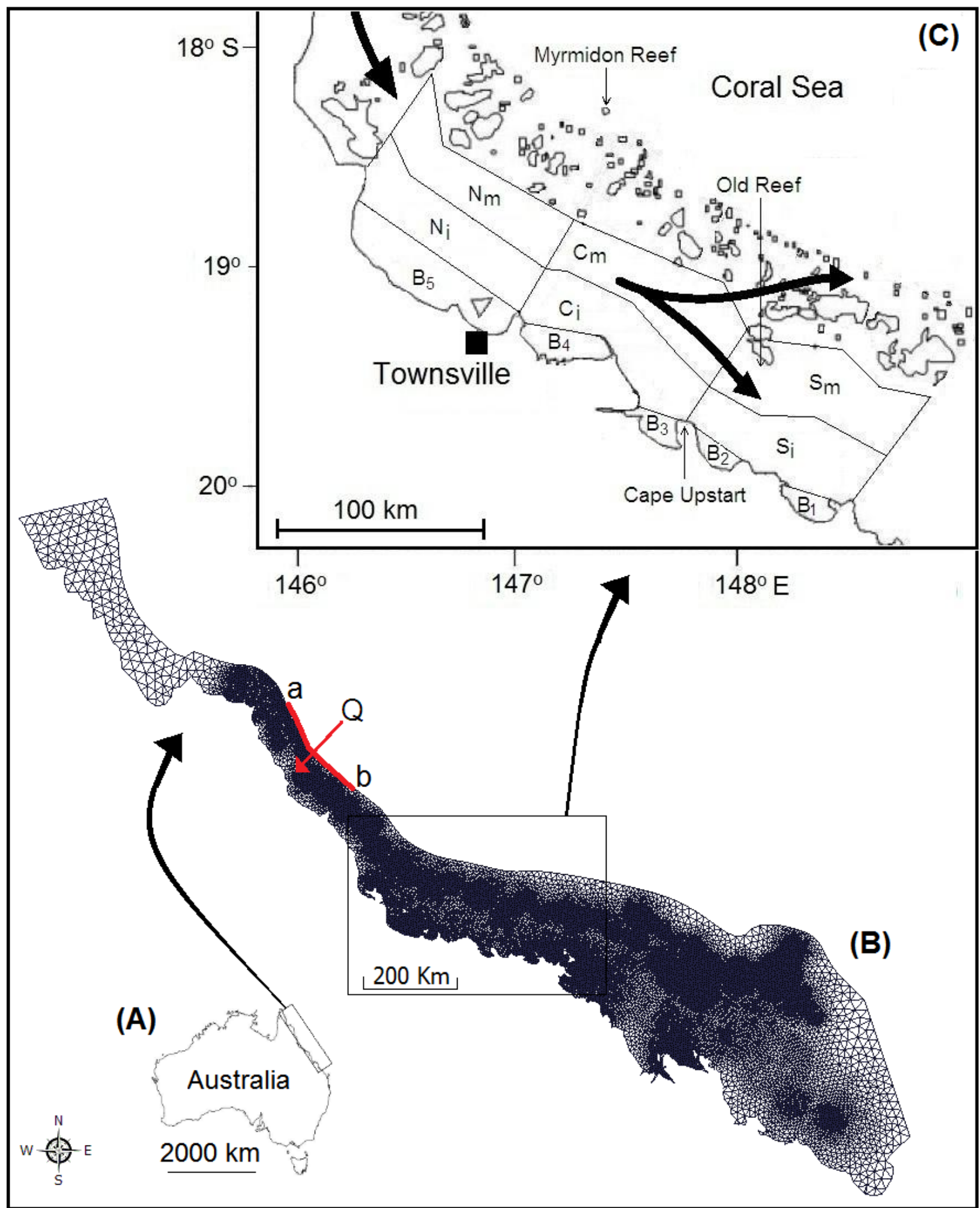


Figure 2.

2

3

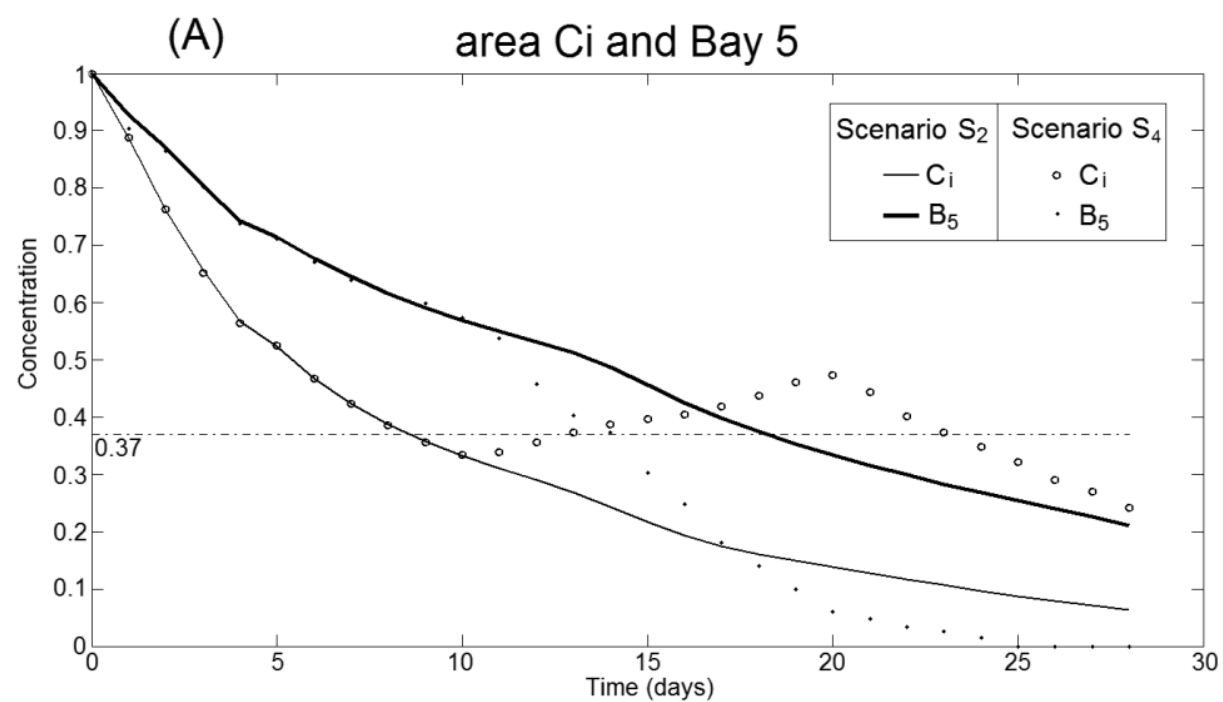

(B) central GBR

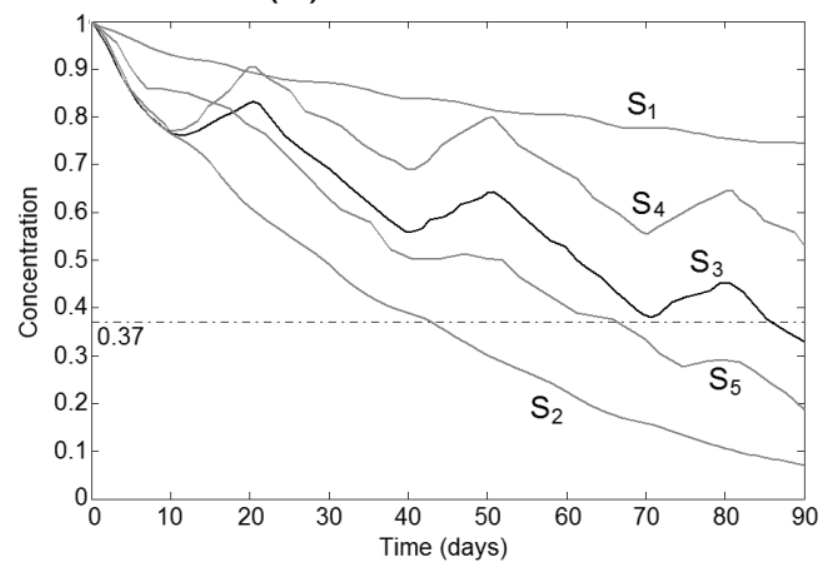

(C) wind

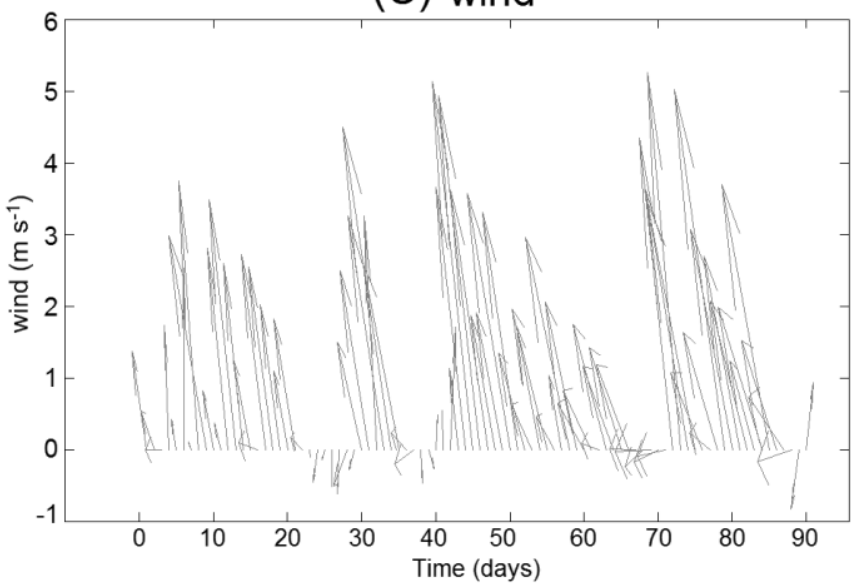

4

5

6 
$1 \quad$ Figure 3.

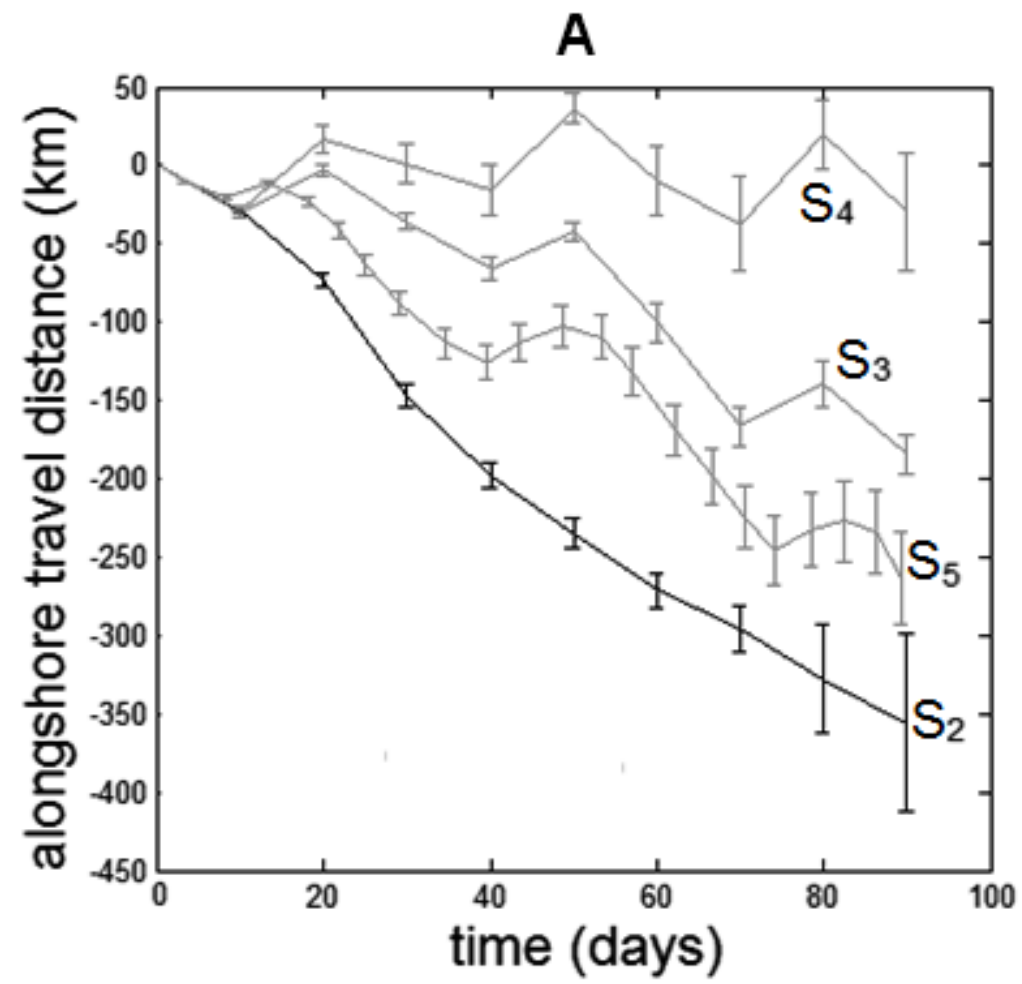

2
3
4
5
6
7
8 
Figure 4.

2 3

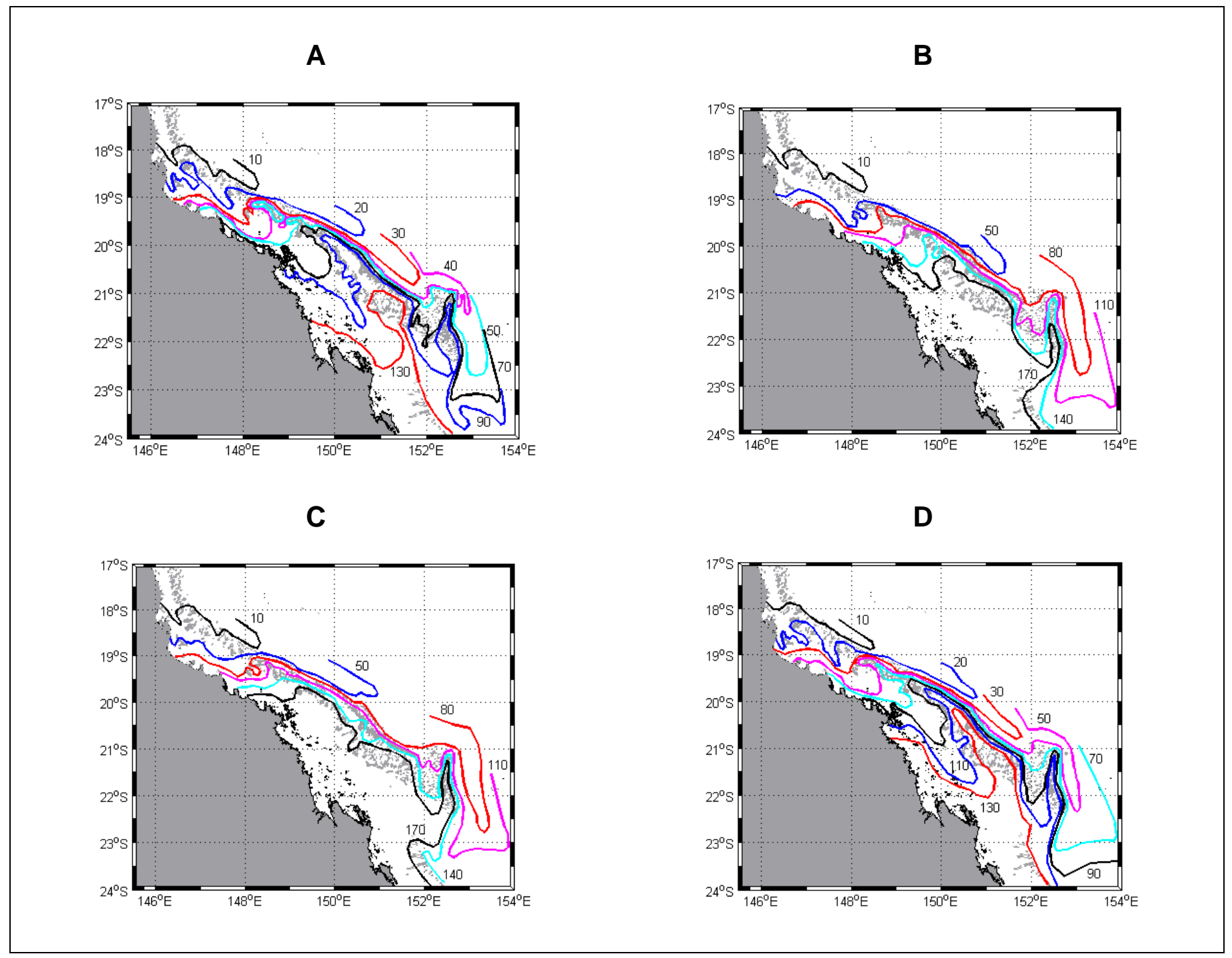


Figure 5.

2

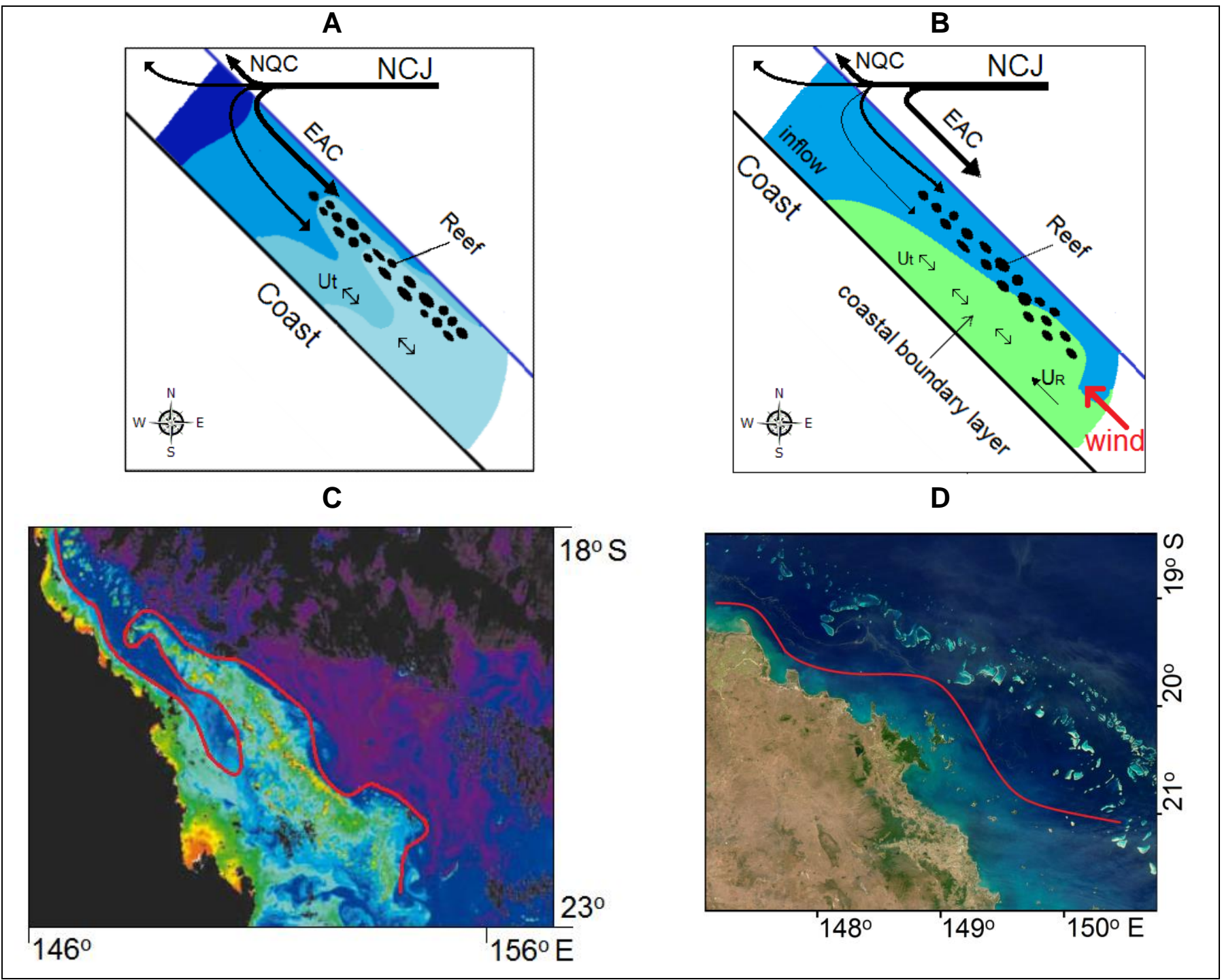

3

4

5

6

7

8

9

10 
1 Table 1 - Five scenarios applied to the numerical simulations to estimate the flushing time and the age 2 of waters in the Great Barrier Reef.

\begin{tabular}{|c|l|}
\hline Condition & \multicolumn{1}{|c|}{ Description of the boundary forcing assumed } \\
\hline $\mathrm{S}_{1}$ & Calm weather (i.e. no wind), zero Coral Sea inflow $(Q=0)$. \\
\hline $\mathrm{S}_{2}$ & Calm weather, Coral Sea inflow $Q=4 \mathrm{~Sv}$. \\
\hline $\mathrm{S}_{3}$ & $\begin{array}{l}\text { Fluctuating southeasterly wind of } 6.67 \mathrm{~m} \mathrm{~s}^{-1} \text { (i.e. moderate wind) occurring in bursts of } \\
10 \text { days followed by } 20 \text { days of calm weather; Coral Sea inflow } Q=4 \mathrm{~Sv} .\end{array}$ \\
\hline $\mathrm{S}_{4}$ & $\begin{array}{l}\text { Fluctuating southeasterly wind of } 10 \mathrm{~m} \mathrm{~s}^{-1} \text { (strong wind) occurring in bursts of } 10 \text { days } \\
\text { followed by 20 days of calm weather; Coral Sea inflow } Q=4 \mathrm{~Sv}\end{array}$ \\
\hline $\mathrm{S}_{5}$ & $\begin{array}{l}\text { Real wind conditions; Coral Sea inflow } Q=4 \mathrm{~Sv} . \text { The real wind simulation starts on } 1^{\text {st }} \\
\text { of August 2006. }\end{array}$ \\
\hline
\end{tabular}


1 Table 2 - Observed $\left(U_{o}\right)$ and predicted $\left(U_{p}\right)$ longshore residual currents in a range for scenarios $\mathrm{S}_{2}$ under 2 calm weather, $S_{3}$ fluctuating wind of $6.67 \mathrm{~m} \mathrm{~s}^{-1}, S_{4}$ fluctuating wind of $10 \mathrm{~m} \mathrm{~s}^{-1}$ and $S_{5}$ for a real wind 3 condition ( $>0$ if northward, $<0$ if southward) and peak tidal currents $\left(U_{T}\right)$ at mooring sites. The wind 4 condition does not affect the tidal currents, and thus $U_{T}$ does not change. Data in this table extracted 5 from Andutta et al. (2011) and Andutta et al. (pers. comm.). The root mean square error for velocity 6 RMSE $\left(\mathrm{m} \mathrm{s}^{-1}\right)$.

\begin{tabular}{|c|c|c|c|c|c|c|c|c|}
\hline \multicolumn{7}{|c|}{ Currents $\left(\mathrm{m} \mathrm{s}^{-1}\right)$ in the GBR at mooring sites } \\
\hline Site name & Lat. $\left({ }^{\circ} \mathrm{S}\right)$ & Lon. $\left({ }^{\circ} \mathrm{E}\right)$ & $U_{o}$ & $U_{p}\left(\mathrm{~S}_{2}\right)$ & $U_{p}\left(\mathrm{~S}_{3}\right)$ & $U_{p}\left(\mathrm{~S}_{4}\right)$ & $U_{p}\left(\mathrm{~S}_{5}\right)$ & $U_{T}$ \\
\hline Lizard Island & 14.7406 & 145.4253 & 0.05 & 0.06 & 0.07 & 0.08 & 0.07 & 0.23 \\
\hline Cape Upstart & 19.6253 & 147.9142 & -0.11 & -0.12 & -0.10 & -0.09 & -0.10 & 0.63 \\
\hline Old Reef & 19.4071 & 148.0197 & -0.10 & -0.11 & -0.09 & -0.08 & -0.09 & 0.59 \\
\hline near shelf break & 18.8311 & 148.2896 & -0.25 & -0.19 & -0.23 & -0.25 & -0.20 & 0.36 \\
\hline Myrmidon Reef & 18.2452 & 147.4100 & -0.18 & -0.20 & -0.21 & -0.24 & -0.25 & 0.52 \\
\hline Bowden Reef & 19.0600 & 147.9597 & -0.02 & -0.03 & -0.02 & -0.01 & -0.02 & 0.47 \\
\hline Rattray Island & 19.9826 & 148.5833 & -0.08 & -0.10 & -0.09 & -0.08 & -0.09 & 0.47 \\
\hline Hook & 19.9400 & 149.1100 & -0.15 & -0.17 & -0.16 & -0.15 & -0.16 & 0.71 \\
\hline Bushy & 20.8900 & 150.1600 & -0.13 & -0.15 & -0.12 & -0.12 & -0.13 & 0.32 \\
\hline Bell & 21.8200 & 151.1400 & -0.06 & -0.08 & -0.06 & -0.05 & -0.06 & 0.45 \\
\hline RMSE & - & - & - & 0.025 & 0.022 & 0.024 & 0.028 & - \\
\hline
\end{tabular}


1 Table 3 - The average flushing time $T$ (in days) and the concentration of a passive tracer (in \%) 2 remaining after 12 and 24 days. The results are for the simulations assuming scenarios $S_{1}, S_{2}, S_{3}, S_{4}$ and $3 \mathrm{~S}_{5}$. Results are for the bays $\mathrm{B}_{1}-\mathrm{B}_{5}$, and the zones $\left(\mathrm{S}_{\mathrm{i}}\right)$ South inshore, $\left(\mathrm{S}_{\mathrm{m}}\right)$ South middle, $\left(\mathrm{C}_{\mathrm{i}}\right)$ Central 4 inshore, $\left(\mathrm{C}_{\mathrm{m}}\right)$ Central middle, $\left(\mathrm{N}_{\mathrm{i}}\right)$ North inshore and $\left(\mathrm{N}_{\mathrm{m}}\right)$ North middle (Figure 1). Central GBR rows show the flushing time for all the zones and bays. The return coefficient $r$ calculated for scenarios $S_{1}$ and $\mathrm{S}_{2}$ was nearly zero, while for scenarios $\mathrm{S}_{3}, \mathrm{~S}_{4}$ and $\mathrm{S}_{5} \mathrm{r}$ is shown in the table.

\begin{tabular}{|c|c|c|c|c|c|c|}
\hline \multicolumn{7}{|c|}{ Two conditions of inflow $Q$, under calm weather condition } \\
\hline \multirow{2}{*}{ Location } & \multicolumn{3}{|c|}{$\mathrm{S}_{1} Q=0 \mathrm{~Sv}$} & \multicolumn{3}{c|}{$\mathrm{S}_{2} Q=4 \mathrm{~Sv}$} \\
\cline { 2 - 7 } & $T$ & $\mathrm{~N}_{1}(12 \mathrm{~d})$ & $\mathrm{N}_{2}(24 \mathrm{~d})$ & $T$ & $\mathrm{~N}_{1}(12 \mathrm{~d})$ & $\mathrm{N}_{2}(24 \mathrm{~d})$ \\
\hline $\mathrm{B}_{1}$ & 21.0 & 53.0 & 34.0 & 20.0 & 52.4 & 33.0 \\
\hline $\mathrm{B}_{2}$ & 6.0 & 21.6 & 10.2 & 3.0 & 5.0 & 17.5 \\
\hline $\mathrm{B}_{3}$ & 18.5 & 47.4 & 29.6 & 9.5 & 34.1 & 0.0 \\
\hline $\mathrm{B}_{4}$ & 18.5 & 46.8 & 29.2 & 14.0 & 40.7 & 19.2 \\
\hline $\mathrm{B}_{5}$ & 41.0 & 66.6 & 53.0 & 18.0 & 53.5 & 27.0 \\
\hline $\mathrm{S}_{\mathrm{i}}$ & 60.0 & 81.0 & 69.9 & 5.5 & 16.7 & 0.0 \\
\hline $\mathrm{S}_{\mathrm{m}}$ & 42.5 & 67.2 & 54.1 & 10.0 & 30.9 & 13.6 \\
\hline $\mathrm{C}_{\mathrm{i}}$ & 37.0 & 62.9 & 48.4 & 8.5 & 28.8 & 9.4 \\
\hline $\mathrm{C}_{\mathrm{m}}$ & 37.0 & 63.5 & 49.3 & 5.0 & 6.1 & 0.0 \\
\hline $\mathrm{N}_{\mathrm{i}}$ & 35.0 & 56.8 & 42.9 & 8.0 & 28.8 & 13.0 \\
\hline $\mathrm{N}_{\mathrm{m}}$ & 37.0 & 61.3 & 49.1 & 11.0 & 35.6 & 16.8 \\
\hline Central GBR & 270 & 92.0 & 88.0 & 43.0 & 74.0 & 56.0 \\
\hline
\end{tabular}

Two conditions of fluctuating southeasterly wind, and the Coral Sea inflow of $4 \mathrm{~Sv}$

\begin{tabular}{|c|c|c|c|c|c|c|c|c|c|c|c|}
\hline \multirow{2}{*}{ Location } & \multicolumn{6}{|c|}{$\mathrm{S}_{3}$ Wind $6.67 \mathrm{~m} \mathrm{~s}^{-1}$} & \multicolumn{5}{|c|}{$\mathrm{S}_{4}$ Wind $10 \mathrm{~m} \mathrm{~s}^{-1}$} \\
\hline & $T$ & $\mathrm{r}$ & \multicolumn{2}{|c|}{$\mathrm{N}_{1}(12 \mathrm{~d})$} & \multicolumn{2}{|c|}{$\mathrm{N}_{2}(24 \mathrm{~d})$} & \multicolumn{2}{|c|}{$T$} & $\mathrm{r}$ & $\mathrm{N}_{1}(12 \mathrm{~d})$ & $\mathrm{N}_{2}(24 \mathrm{~d})$ \\
\hline $\mathrm{B}_{1}$ & 14.0 & - & \multicolumn{2}{|c|}{47.1} & \multicolumn{2}{|c|}{6.8} & \multicolumn{2}{|c|}{13.4} & - & 43.0 & 2.5 \\
\hline $\mathrm{B}_{2}$ & 2.7 & - & \multicolumn{2}{|c|}{0.0} & \multicolumn{2}{|c|}{0.0} & \multicolumn{2}{|c|}{2.7} & - & 0.0 & 0.0 \\
\hline $\mathrm{B}_{3}$ & 10.0 & - & \multicolumn{2}{|c|}{28.5} & \multicolumn{2}{|c|}{0.0} & \multicolumn{2}{|c|}{10.0} & - & 26.1 & 0.0 \\
\hline $\mathrm{B}_{4}$ & 12.5 & - & \multicolumn{2}{|c|}{38.8} & \multicolumn{2}{|c|}{1.6} & \multicolumn{2}{|c|}{11.7} & - & 35.2 & 0.0 \\
\hline $\mathrm{B}_{5}$ & 15.0 & - & \multicolumn{2}{|c|}{49.2} & \multicolumn{2}{|c|}{11.0} & \multicolumn{2}{|c|}{14.0} & - & 45.8 & 1.4 \\
\hline $\mathrm{S}_{\mathrm{i}}$ & 5.5 & - & \multicolumn{2}{|c|}{24.1} & \multicolumn{2}{|c|}{15.4} & \multicolumn{2}{|c|}{7.4} & 0.26 & 26.3 & 25.2 \\
\hline $\mathrm{S}_{\mathrm{m}}$ & 22.9 & - & 38. & & & 5.1 & & & - & 38.9 & 42.5 \\
\hline $\mathrm{C}_{\mathrm{i}}$ & 17.2 & 0.51 & 36 & & & 1.5 & & & 0.55 & 35.8 & 35.1 \\
\hline $\mathrm{C}_{\mathrm{m}}$ & 5.0 & - & 11. & & & 3.0 & & & - & 10.7 & 2.0 \\
\hline $\mathrm{N}_{\mathrm{i}}$ & 13.4 & 0.40 & 34. & & & 1.1 & & & 0.54 & 34.6 & 32.4 \\
\hline $\mathrm{N}_{\mathrm{m}}$ & 22.0 & - & 38. & & & 2.8 & & & - & 39.5 & 40.0 \\
\hline Central GBR & 86.0 & - & 76 . & & & 6.9 & & & - & 78.4 & 86.2 \\
\hline & & & $\mathrm{S}_{5}$ real win & , an & $\mathrm{e} \mathrm{C}$ & $\mathrm{al} \mathrm{Sea}$ & flo & $\mathrm{V}$ of 4 & & & \\
\hline Location & $T$ & $\mathrm{r}$ & $\mathrm{N}_{1}(12 \mathrm{~d})$ & & & Loca & & $T$ & & $\mathrm{~N}_{1}(12 \mathrm{~d})$ & $\mathrm{N}_{2}(24 \mathrm{~d})$ \\
\hline $\mathrm{B}_{1}$ & 20.4 & - & 57.3 & & & $\mathrm{~S}$ & & 11.5 & & 36.5 & 11.7 \\
\hline $\mathrm{B}_{2}$ & 3.8 & - & 14.0 & & & $\mathrm{~S}_{\mathrm{r}}$ & & 10.4 & & 33.2 & 6.1 \\
\hline $\mathrm{B}_{3}$ & 11.2 & - & 35.3 & & & $\mathrm{C}$ & & 13.1 & & 38.8 & 17.2 \\
\hline $\mathrm{B}_{4}$ & 10.7 & - & 32.7 & & & $\mathrm{C}_{\mathrm{I}}$ & & 5.1 & & 11.1 & 0.0 \\
\hline $\mathrm{B}_{5}$ & 30 & - & 63.4 & & & $\mathrm{~N}$ & & 9.9 & & 34.3 & 17.0 \\
\hline Central GBR & 67.0 & - & 87.0 & & & $\mathrm{~N}_{1}$ & & 10.8 & & 34.2 & 9.9 \\
\hline
\end{tabular}

